\title{
Субъектно-образные структуры в татарской и тувинской поэзии 1970-1990-х гг.
}

\author{
Венера Р. Аминева \\ Казанский (Приволжский) федеральный университет; Институт мировой литературы им. А. М. Горького \\ Российской академии наук, Российская Федерация,
} Людмила С. Мижит

Тувинский институт гуманитарных и прикладных социально-экономических исследований при Правительстве Республики Тыва, Российская Федерация

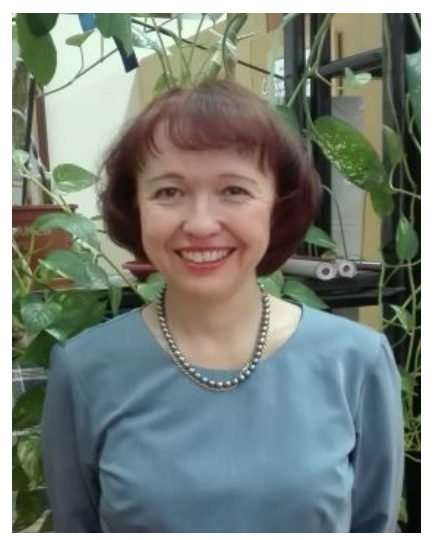

На материале произведений татарских (И. Юзеева, Р. Ахметзянова, Р. Гаташа) и тувинских поэтов (А. Уержаа, А. Даржая, Э. Мижита, Н. Куулара) выявляются складывающиеся в татарской и тувинской поэзии 1970-1990-х г2. типы субъектно-образных ситуаций. Они исследуются как сфера проявления национальной идентичности художественного текста и область, в которой отражаются сходные тенденции историко-литературного процесса этих лет. В решении поставленных задач были использованы системно-структурный, сравнительный и герменевтический методы исследования.

Выделены основные типы субъектно-образных ситуаций в творчестве поэтов, отражающие пути самоопределения лирического субъекта. Сделан вывод о том, что лирические герои И. Юзеева и А. Уержаа стремятся занять позицию авторефлексивной вненаходимости по отношению к самому себе, что выводит субъектно-образную целостность произведения на уровень метаизображения. В художественной системе Р. Ахметзянова и А. Даржая «я» оказывается, с одной стороны, вероятностно-множественным, не совпадающим с самим собой, а с другой - синкретическим, совмещающим в себе два вида сознания - народно-мифологическое и индивидуально-творческое. Установлено, что специфика субъектно-образной целостности лирики татарских и тувинских поэтов раскрывается и в отношениях «я» с субъектами осо-

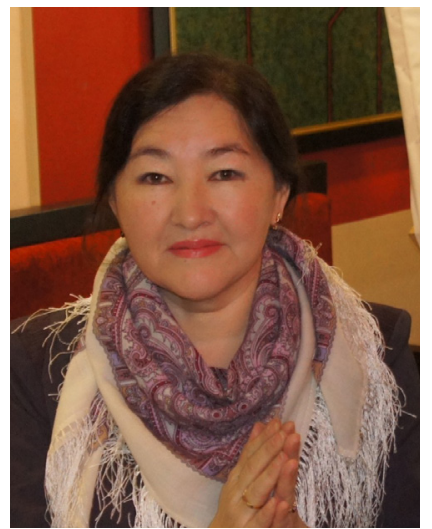
бого типа, точнее - сверхсубъектами. Они воплощают надличностное и вненаходимое по отношению к основной лирической ситуации и ее героям активно-волевое начало.

Самостоятельными действующими лицами, обладающими бытийной полновесностью, выступают в стихотворениях Р. Ахметзянова, Э. Мижита, Р. Гаташа, А. Уержаа, Н. Куулара стихии природы, любви и творчества. В диалогической обращенности к этим сверхсубвектам, стоящим за пределами сознания «я», выявляется жизненно-творческая позииия «героя» и «автора». Решающая роль в создании выделенных типов субъектно-образных структур в татарской и тувинской поэзии данного периода принадлежит мифопоэтическим «языкам» кумуляции и параллелизма. Они вступают во взаимодействие с условно-поэтическим словом, указывающим на относительность бытийного плана образа и задающим в каждом конкретном случае его предель.

Полученные результаты значимы для построения исторической поэтики татарской $и$ тувинской литературы 2-й половины ХХ в.

Ключевые слова: национальная литература; татарская поэзия; тувинская поэзия; татарская литература; тувинская литература; лирика; лирический герой; поэтика; татары; тувинцы; субъектно-образные структуры

\section{Для цитирования:}

Аминева В. Р., Мижит Л. С. Субъектно-образные структуры в татарской и тувинской поэзии 1970-1990-х гг.// Новые исследования Тувы. 2021, № 1. С. 228-254. DOI: https://www.doi.org/10.25178/nit.2021.1.13

Аминева Венера Рудалевна - доктор филологических наук, доцент, профессор кафедры русской и зарубежной литературы Института филологии и межкультурной коммуникации Казанского (Приволжского) федерального университета; ведущий научный сотрудник Отдела литератур народов России и СНГ Института мировой литературы им. А. М. Горького Российской академии наук. Адрес: 480008, Россия, г. Казань, ул. Кремлевская, д. 18; 121069 , Россия, г. Москва, ул. Поварская, д. 25 а. Тел.: +7 (905) 039-04-99. Эл. адрес: amineva1000@list.ru

Мижит Людмила Салчаковна - кандидат филологических наук, ведущий научный сотрудник отдела культурологии и религиоведения Тувинского института гуманитарных и прикладных социально-экономических исследований при Правительстве Республики Тыва. Адрес: 667000, Россия, г. Кызыл, ул. Кочетова, д. 4. Тел.: + 7 (963) 252-34-09. Эл. aдрес: lmizhit@ mail.ru 


\title{
Subject-figurative structures in Tatar and Tuvan poetry of the 1970s - 1990s
}

\author{
Venera R. Amineva \\ Kazan Federal University; Gorky Institute of World Literature, Russian Federation, \\ Lyudmila S. Mizhit \\ Tuvan Institute of Humanities and Applied Social and Economic Research under the Government of the Republic of Tuva, \\ Russian Federation
}

The article identifies several types of subject-figurative situations in Tatar and Tuvan poetry, taking the works of Tatar and Tuvan poets (I. Yuzeyev, R. Akhmetzyanov, R. Gatash, A. Uerzhaa, A. Darzhay, E. Mizhit, N. Kuular) for its sources. These literary situations are investigated as manifestations of the national identity in a literary text, and as a cultural space that reflects similar trends in the historical and literary process. The paper relies on systemic-structural, comparative, and hermeneutic methods of research.

The authors examine the main types of subject-figurative situations in the work of poets which reflect the ways of self-determination of the lyrical subject. They conclude that I. Yuzeev's and A. Uerzhaa's lyrical protagonist seek to take a position of self-reflective "outsidedness" in relation to himself, which brings the subject-figurative integrity of their work to the meta-image level. R. Akhmetzyanov's and A. Darzhay's lyrical subject turns out to be probabilistically plural, not coinciding with itself. At the same time, it syncretically combines two types of consciousness - folk-mythological and individualized. The study postulates that the specificity of the subject-figurative integrity in Tatar and Tuvan poetry manifests itself in the relationship between the "I" and what may be termed 'super-subjects', which personify the active volitional power with its supra-personal "outsidedness" influencing the lyrical situation and its heroes.

Elements of life, nature, love, and creativity acquire full agency in poems by R. Akhmetzyanov, E. Mizhit, R. Gatash, A. Uerzhaa, and N. Kuular. Vital and creative position of the "lyrical protagonist" and "author" is revealed in this dialogical appeal to the supersubjects which transcend individual consciousness. Mythopoetic "languages" of cumulation and parallelism play a decisive role in setting the types of abovementioned subject-figurative structures in Tatar and Tuvan poetry of the 1970s-1990s. They interact with the conditionally poetic language that indicates the relativity of the existential plane of the poetic imagery and sets its limits in each specific case.

The outcomes of the study can be important for developing the historical poetics of Tatar and Tuvan literature of the latter half of the 20th century.

Keywords: national literature; Tatar poetry; Tuvan poetry; Tatar literature; Tuvan literature; lyrics; lyrical protagonist; poetics; Tatars; Tuvans; subject-image structures

\section{For citation:}

Amineva V. R. and Mizhit L. S. Subject-figurative structures in Tatar and Tuvan poetry of the 1970s - 1990s. New Research of Tuva, 2021, no. 1, pp. 228-254. (In Russ.). DOI: https://www.doi.org/10.25178/nit.2021.1.13

AMINEVA, Venera Rudalevna, Doctor of Philology, Professor, Department of Russian and Foreign Literatures, Kazan Federal University; Leading Research Fellow, Department of Literature of Russia's Ethnicities and the CIS Countries, A.M. Gorky Institute of World Literature. Postal address: 18 Kremlyovskaya St., 420008 Kazan, Russian Federation; 25a Povarskaya St., 121069 Moscow, Russia. Tel.: +7 (905) 039-04-99. E-mail: amineva1000@list.ru

MIZHIT, Lyudmila Salchakovna, Candidate of Philology, Leading Research Fellow, Department of Cultural and Religious Studies, Tuvan Institute of Humanities and Applied Social and Economic Research under the Government of the Republic of Tuva. Postal address: 4 Kochetov St., 667000 Kyzyl, Russian Federation. Tel.: + 7 (963) 252-34-09. E-mail: lmizhit@mail.ru 


\section{Введение}

Кризис социалистического образа жизни в СССР, усиленный масштабным сопротивлением государственной идеологии, отказом художников от социальной реальности (Имихелова, Болдонова, 2017: 149), привел к тому, что в 1970-1990-е гг. актуализируются проблемы идентификации «я» как комплексной деятельности личности по самосознанию и самоопределению. Испытывая давление внешних обстоятельств, человек стремился к важному для него моменту самопознания, обретения истинного «я» и подлинного содержания собственной жизни. Не приемля существующих социальных связей, он одухотворен поиском нового - гармонического единения с началами общими, как социально-историческими (нацией, народом, человечеством), так и универсальными (природой, мирозданием, вселенной). Исследователи этого периода в истории русской литературы констатируют: «Прорыв из-под глыб тоталитарного сознания, который начался в годы “оттепели”, расшатывание жесткой парадигмы соцреализма и поиски иных путей художественного освоения действительности уже не удалось остановить в годы политического застоя и идеологических “заморозков” (Лейдерман, Липовецкий, 2001: 10).

Процессы, происходившие в духовной жизни страны, нашли отражение в многонациональной советской литературе, в частности, в творчестве целого ряда выдающихся поэтов - татарских, тувинских, украинских, литовских, армянских, грузинских, Северного Кавказа, Калмыкии, Чувашии и др. В истории татарской литературы этот период рассматривается учеными как время поиска новых эстетических ориентиров, экспериментов в области содержания, художественных средств и приемов (см.: Заһидуллина, Йосыпова, 2011). Сходные тенденции наблюдаются и в других литературах. Например, духом экспериментаторства были охвачены чувашские поэты: «Период “оттепели” способствовал новой реформе чувашской поэзии, которая заключалась в отказе ряда поэтов-новаторов от силлабо-тонической метрики, фабульности и шаблонной образности. Лирическое «я» в их стихотворениях стало более свободным и индивидуальным, требующим от читателя усиленного внимания к сцеплению рядом стоящих образов, их тональности, звучанию полутонов» (Родионов, Родионова, 2019: 45-46). Сложные, противоречивые переживания, порожденные эпохой, в аварской поэзии 1960-1980-х гг., как показывает 3. З. Гаджиева, передаются в форме исповеди, восходящей к жанру «тавбу»: «В исповедальных произведениях ощущается пульсирование нарастающей тревоги, гнетущей поэтов, нежелание примириться с действительностью, чувство испытываемого дискомфорта, и они проводят неустанный самоанализ, а лирическое «я» становится не только субъектом, но и объектом такого познания» (Гаджиева, 2015: 107). Лирический герой Р. Гамзатова вопрошает: «Кто я такой?», «... опавший лист или ветка в листве?» (там же: 112). Об извечной потребности «заглянуть внутрь себя», «обратиться к своему затаенному “я”» пишет бурятский поэт Б. Дугаров (Имихелова, Болдонова, 2017: 154). Новые пути самовыражения ищут удмуртские поэты Ф. И. Васильев, А. Е. Белоногов, В. М. Ванюшев (Шибанов, 2012); абазинский поэт М. Чикатуев (Псху, 2007).

В татарской поэзии основные тенденции в развитии субъектных отношений и сопряженных с ними образных структурах отразились в творчестве Равиля Файзуллина, Ильдара Юзеева, Роберта Ахметзянова ${ }^{1}$, Шамиля Анака, Радифа Гаташа и других. В тувинской литературе показательно в этом плане творчество Антона Уержаа, Эдуарда Мижита, Александра Даржая, Николая Куулара. Известный литературовед А. К. Калзан отмечает, что эти поэты отказались от господствовавшей многие годы публицистической поэзии и являются истинными лириками, выражающими внутренний мир, душу личности (Калзан, 1991: 24).

Творчество татарских и тувинских поэтов представляется достаточно изученным в литературоведении в аспекте идейно-тематического содержания, сквозных образов и мотивов их лирики (Баянов, 1985; Ганиева, 2009; Миңнегулов, 1995; Калзан, 1991; Самдан, 2005; Тыва чечен чогаал ... , 2009; Донгак, 2014; Мижит, 2015), новаторских поисков и экспериментов (см.: Загидуллина, 2015; Мижит, 2013). Вместе с тем складывающиеся в произведениях И. Юзеева, Р. Ахметзянова, Р. Гаташа, А. Уержаа, Э. Мижита, А. Даржая, Н. Куулара субъектно-образные структуры до сих пор не становились предметом специального научного исследования. Однако они важны для понимания художественноэстетической природы процессов, происходящих в это время в национальных литературах, а также для построения их исторической поэтики.

\footnotetext{
${ }^{1}$ В данной работе речь будет идти о творчестве Роберта Ахметзянова, в это же время творил и его однофамилец - поэт Рашид Ханифович Ахметзянов (1941-1995).
} 
В данной статье впервые проводится сопоставительный анализ произведений татарских и тувинских поэтов, созданных в 1970-1990-е гг., с целью раскрыть содержание и особенности проявления действующей в разных национальных литературах сходной тенденции - развития и обогащения субъективного начала, все большей индивидуализации лирического героя, вызывающих усложнение структуры субъектной сферы лирики и соответствующей ей образности. Вместе с тем различия, фиксируемые на разных уровнях художественной системы поэтов, значимы для понимания национальной идентичности находящихся в диалоге литератур.

Наряду с произведениями поэтов, пишущих на татарском и тувинском языках, в статье рассматриваются и русскоязычные тексты писателей-билингвов, в творчестве которых актуализируются коды национальной культуры и отражаются особенности национального менталитета.

На концепцию работы оказали влияние труды М. М. Бахтина, различающего «первичного» и «вторичного» автора (Бахтин, 1986а: 297-325), Б. О. Кормана, предложившего методику анализа авторского сознания и форм его выражения в тексте (Корман, 2006: 110-221), С. Н. Бройтмана, обосновавшего ряд теоретических понятий и принципов анализа субъектно-образной структуры лирического произведения (Бройтман, 1997).

В решении задач, связанных с сопоставлением творчества поэтов, принадлежащих к разным национальным литературам, мы опираемся на сложившиеся в отечественной и зарубежной компаративистике традиции сравнительного изучения национальных литератур, в соответствии с которыми принято выделять две основные формы межлитературного процесса: контактные связи и типологические схождения (Дюришин, 1979). В то же время данное исследование находится в контексте идей М. М. Бахтина о диалоге как особом виде смысловых отношений, акцентирующих понимание эстетического объекта как бытийно-эстетического образования, в основе которого лежат персонологические и имманентно-социальные отношения между субъектами - «я» и «другим», автором и героем, произведением и читателем (Бахтин, 1986а).

В работе «К методологии гуманитарных наук» М. М. Бахтин, поставив проблему «контекстов понимания» и разграничив малое время современности и большое время, «близкий» и «далекий» контексты, пишет о нескончаемом обновлении смыслов во все новых контекстах (там же: 381-393). В качестве такого «контекста понимания» в нашем исследовании выступает национальная литературно-художественная традиция, являющаяся своеобразным диалогизирующим фоном для восприятия другой национальной литературы. При этом позиция «вненаходимости» одной литературы по отношению к другой дает возможность иного, нового ее видения, недоступного взгляду «изнутри», позиции самонаблюдения (Yuzmukhametova, Amineva, Shimonik, 2018).

\section{«Определения» в татарской и тувинской поэзии: пути самоидентификации лирического субъекта}

В поэтическом творчестве татарских и тувинских писателей, создававших произведения в 1970-1990-х годах, прослеживается процесс самоопределения и самоидентификации лирического «я», устремленного к широким и гармоническим связям со своей нацией, миром природы, человечеством, вселенной. Так, опосредованно, через образы родины, родного народа, любимых людей и личное отношение к ним определяется место лирического героя в мире и его внутренняя сущность.

Важным шагом в утверждении самоценности внутреннего мира человека стала поэзия И. Юзеева ${ }^{1}$ и А. Уержаа ${ }^{2}$, лирический субъект которых пребывает в состоянии саморефлексии, осознания связи своего «я» с сущностными вопросами бытия. Субъектно-образная и ценностная архитектоника таких стихотворений И. Юзеева, как: «Күңелем минем - чиксез кара урман» («Моя душа - бескрайний темный лес»), «һәрнәрсәгә карыйм исем китеп» («На все восторженно гляжу»), «Юк, мин яши алмыйм алай...» («Нет, я так жить не могу...»), «Шом» («Тревога»), «Борчылу» («Беспокойство»), «Нишләдем?..» («Что я наделал?»), «Гадәт-холкым белән - кыр казы мин...» («Характером - я дикий гусь...»), «Кемнәр

${ }^{1}$ Юзеев Ильдар Гафурович (1933-2004) - Народный поэт Республики Татарстан, лауреат Государственной премии РТ им. Г. Тукая. Родился в деревне Ямады Янаульского района Башкирской АССР. Автор более 30 сборников поэзии и драматургии.

${ }^{2}$ Антон Уержаа (Кужугет Антон Уержааевич) (1957-1996) - тувинский поэт, лауреат премии комсомола Тувы. Родился в с. Хонделен Барун-Хемчикского района Тувинской автономной области. Автор 5 поэтических сборников. 
үтәр?» («Кто пройдет?»), «Тормыш ул - серле бер могжиза» («Жизнь - тайна»); стихотворений А. Уержаa, как: «Саарыг ыры» («Песнь водопада»), «Эрткен үем шынаазынга» («В долине моего прошлого»), «Чыннып алган шырайларым одаглары» («Костры лиц, у которых я согревался»), «Ынак-тыр мен...» («Я люблю...»), «Ыглаан сен бе?» («Плакал ли ты?») - характеризуется направленностью на процесс самопознания и самоидентификации.

Так, стихотворение «Кемнәр үтәр?» («Кто пройдет?») И. Юзеева структурировано определением, выполняющим идентифицирующую функцию: «Я - вечная материя». Эта общая формула получает последовательную конкретизацию, которая воссоздает извечный природно-космический цикл, подчиняющий отдельное человеческое существование своим законам и ритмам. Перечисление основных психо-эмоциональных состояний, переживаемых «я», наполняет космическую первоэнергию непосредственным человеческим содержанием:

Кемнәр үтәр?

Мин - мәңгелек материя,

хәзергә - жанлы адәм:

яшим,

тоям,

сөям,

елыйм,

кычкырып көлә алам...

Жиңәм,

жиңеләм,

картаям, -

яшәүдән китә барам ${ }^{1}$.
Я - вечная материя,

пока - живой человек,

чувствую,

люблю,

плачу,

могу громко смеяться...

Побеждаю,

оказываюсь побежденным,

старею, -

ухожу из жизни.

(Пер. В. Аминевой $)^{2}$

Этот семантический ряд, состоящий из любви, слез, громкого смеха, победы, поражения, старения и умирания, формирует микрокосм человеческого бытия в нерасчленимости в нем радости и страдания, активности и пассивности, длительности и краткости и одновременной устремленности к полноте самореализации. Самосознание «я» - это и чувство своего предсуществования в иной форме бытия. Активно-пассивное движение, ориентированное центростремительно, во второй строфе сменяется центробежным, диссоциирующим. Возникает разнообразие форм, являющихся субститутами «я»:

Мин - мәңгелек материя,

гел жанлы булып калмам:

таш,

туфрак,

яфрак булырмын,

тик көлә генә алмам... ${ }^{3}$
Я - вечная материя,

не всегда буду живым,

стану камнем,

землей,

листком,

только не смогу смеяться...

Поставленные в один смысловой ряд образы камня, земли, листка образуют единую синкретическую реальность, в которой нет границ между природой и человеком, живым и неодушевленным, органическим и неорганическим, био- и семиосферой, «я» и «не-я».

Наконец мышление о себе неотделимо от ориентации на «другого» - того, кто будет помнить обо «мне»:

${ }^{1}$ Юзеев И. Мәңге ян, күңел: шигырьләр, жырлар, балладалар, поэма [Душа, гори вечно: стихи, песни, баллады, поэма]. Казан: Татар. кит. нәшр., 2012. С. 97. (На татар. яз.).

${ }^{2}$ Подстрочный перевод с татарского языка здесь и далее (без иных указаний) выполнен В. Р. Аминевой.

${ }^{3}$ Юзеев И. Мәңге ян, күңел: ... С. 97. 
Мин - мәңгелек материя, берни дә тоймас формада жиргә кайтырмын урап... Кемнәр үтәр өсләремнән сагынып, көлеп, елап?..
Я - вечная материя, я вернусь на землю, как бесчувственная форма... Кто пройдет по мне, тоскуя, смеясь, плача?..

Несмотря на воскрешающую функцию памяти, этот вопрос, как и сожаление, высказанное во второй строфе («... только не смогу смеяться»), выводит «я» из спасительного цикла вечного возвращения и возрождения, препятствуя его растворению во всеединстве. Цикличности, с которой связаны вечность, всеобщность, мифология, противопоставляется линейность - историческое время, уникальность и неповторимость индивидуальной человеческой судьбы, необходимость для каждого личностно-окрашенного восприятия его жизни «другим». Механизм взаимодействия лирического субъекта с границами - личной (его судьба) и событийной (роль в жизни «другого») - одинаков, что подчеркивается сходством эмоционально-психологических реакций «я» и «другого». Смех и слезы обозначают постижение каждым из них места человека в мире. Предчувствие этого провиденциальновероятностного совпадения «я» и «другого» перестраивает всю перспективу изображаемого, открывая в нем новые связи и отношения. Напряженная экспрессия финального вопроса, маркируя черту, разделяющую поэтическую и внехудожественную реальности, указывает на особое состояние лирического субъекта, творческая мысль которого готова переступить эту черту и устремиться в необозримость самого бытия.

В творчестве А. Уержаа складывается субъектная ситуация, также, как в лирике И. Юзеева, основанная на отделении от «я» его субститутов и превращении их в самостоятельных субъектов. Например, в стихотворении «Эрткен үем шынаазынга» («В долине моего прошлого») совесть становится лебедем, прошлое лирического героя объективируется в пространственном образе забытой долины:

Арын-нүүрүм өскүс-чаңгыс куу болуп, Алгырбышаан, талыгырже кылыйтыпты.

Узудаксап ырай берген куштуң соондан

Уттупканым шынаа-шыкка тояап келдим ${ }^{2}$.
Лебедем став одиноким, совесть моя

Вдаль полетела, криком тоскливо

маня.

Следом за птицей, что отдалилась давно,

Брел я, и вот - долина, забытая мной.

(Пер. Э. Мижита) $)^{3}$

Конкретно-материальные формы приобретают такие понятия, как грусть, радость, «печали седые виски»:

\footnotetext{
${ }^{1}$ Юзеев И. Мәңге ян, күңел: шигырьләр, жырлар, балладалар, поэма [Душа, гори вечно: стихи, песни, баллады, поэма]. Казан: Татар. кит. нәшр., 2012. С. 97. (На татар. яз.).

${ }^{2}$ Уержаа А. К. Ынак-тыр мен...: Шүлүктер, шүлүглелдер, чечен чугаалар [Я люблю... : Стихи, поэмы, рассказы]. Кызыл: Тываның ном үндүрер чери, 1997. С. 83. (На тув. яз.).

${ }^{3}$ Здесь и далее перевод стихотворений А. Уержаа с тувинского Э. Мижита.
} 
Өөрүшкүм хырайлыккан чалгыннары

Өкпең-кызыл бүрүлер бооп

$$
\text { шылырашты. }
$$

Кударалым агарарган кастыктары

Кужур болуп, дөңгеликте чайнап

$$
\text { чыдыр. }
$$

Эргим, таныш овур, үннер

шывараңнап,

Эзин-хатка ыш дег тарап, чидип туру ${ }^{1}$.
Крылья радости той отцвели, словно

сад,

Тихо-тихо листвой красноватой

шуршат.

И печали той самой седые виски

Тоже здесь - вот блестят солонцом

бугорки.

Сердцу милые образы и голоса,

Лишь мелькнув, исчезают, как дым в

небесах.

Эмоционально-психологические состояния лирического героя распространяются на окружающий человека мир и предстают разлитыми в природных явлениях и процессах. Однако этому процессу ослабления сферы субъективности противостоит другая тенденция. Из целостной и эпически завершенной «долины прошлого» выделяется личность, самосознание которой выражается в вопросах:

Омакшылым, ынакшылым, идегелим

Оскундуруум кайыын дилеп,

$$
\text { сураглаайн? }
$$

Чаңгыланган өткүт ыржым

$$
\text { ыыттавады... }
$$

Шапкын хем-не эрткен өйже агып

$$
\text { чыдыр. }
$$

Шак ол хемниң кырын дургаар дескинип,

Чаңгыс ак куш ондап-остап эдип туру.

Аарышкым аймап-дүүрээн куузу бе?

Уттуушкунум улчуп-тояан ыйбазы

бе $?^{2}$
О, любовь! О, радость! О, надежды

мои! -

Где искать мне тех лет все утраты

свои?

Звонким эхом в ответ мне молчит

$$
\text { тишина, }
$$

Лишь река все течет к тем былым временам.

Только белая птица одна все кричит И над бурной рекою летая, скорбит.

Это лебедь встревоженной боли моей?

Пепел мною забытой поры ли над ней?

В вопросах, которыми завершается стихотворение, отражается распад эпической целостности человека, несовпадение героя и его судьбы. Осознание необратимости времени и сомнения в возможности преодоления границ своего «я» выражаются в крике белой птицы и отождествлении облаков с пеплом «забытой поры».

В стихотворении «Кто пройдет?» лирический субъект Юзеева рассматривает себя как носителя общеродовой субстанции человечества. В двух других «определениях»: «Характером - я дикий гусь...» и «Что я наделал?..» - отражается процесс самоидентификации «я» как неповторимой индивидуаль-

1 Уержаа А. К. Ынак-тыр мен...: Шүлүктер, шүлүглелдер, чечен чугаалар [Я люблю... : Стихи, поэмы, рассказы].

Кызыл: Тываның ном үндүрер чери, 1997. С. 83. (На тув. яз.).

${ }^{2}$ Там же. С. 84. 
ности. В первом из этих стихотворений Юзеев развертывает мифосемантический потенциал образа птицы. Между «я» и «диким гусем» возникает особого рода смысловая связь, основанная на их бытийно-субъектном взаимопроникновении. Конкретизированное перечисление признаков, характеризующих лирического субъекта, осуществляется в направлении от способов перемещения в пространстве (плаваю, летаю), траектории движения (устремленное вдаль и возвращающееся к исходной точке) к душевным состояниям:

Гадәт-холкым белән - кыр казы мин:

очам,

йөзәм,

китәм

һәм кайтам...

Гадәт-холкым белән - кыр казы мин:

сагынам,

түзәм,

әрним,

югалтам... ${ }^{1}$

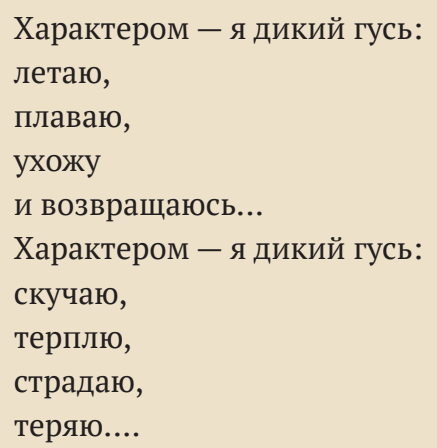

В образном комплексе, ознаменованном орнитологической символикой, наиболее значимой в плане семантико-функциональной изобразительности оказывается способность летать. Она развивает тему эквивалентности «жизни» и «полета» как освобождения от земной тяжести тела и перехода из реального мира в идеальный, состояния воодушевления и энтузиазма духовной жизни, предельной экзистенциальной интенсивности и пафоса. Умение летать подчеркивает не только исключительность героя, но и его трагическую уязвимость и обреченность, враждебность к нему всех тех, кто лишен этой способности:

Гадәт-холкым белән - кыр казы мин:

очмаучылар -

сәер,

ят алар...

Бәлки,

мине

аңлый алмаучылар

беркөн йөрәгемә атарлар...2
Характером - я дикий гусь:

те, кто не умеют летать, -

странные,

чужие...

Может быть,

те, кто не могут меня понять,

однажды выстрелят мне в сердце....

Предчувствие лирическим героем своей трагической судьбы сопровождается переходом на точку зрения авторефлексивной вненаходимости по отношению к самому себе:

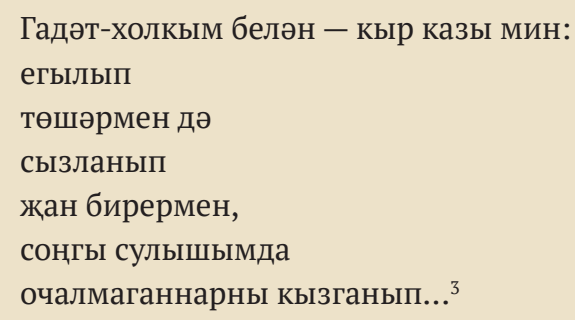

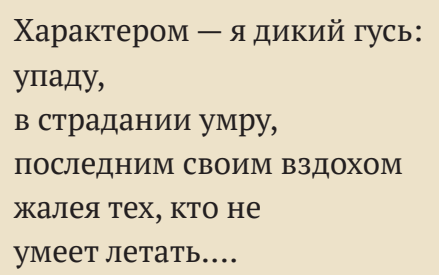

Жалость, обращенная к странным, враждебным по отношению к герою существам, готовым убить, свидетельствует о преодолении им своей жертвенно-страдательной позиции, обнаруживая со-

\footnotetext{
${ }^{1}$ Юзеев И. Мәңге ян, күңел: шигырьләр, жырлар, балладалар, поэма [Душа, гори вечно: стихи, песни, баллады, поэма]. Казан: Татар. кит. нәшр., 2012. С. 92. (На татар. яз.).

${ }^{2}$ Там же.

${ }^{3}$ Там же.
} 
вершенно очевидные признаки как духовного возвышения «я», резко отделяющего себя от других, так и его безусловного превосходства над теми, кто не умеет летать.

В стихотворении «Саарыг-дыр мен» («еснь водопада») А. Уержаа воспроизводится генезис лирического «я» из ледниковых вод:

Саарыг-дыр мен.

Хөөн-чүрээм, челээш ышкаш,

Көвей чүзүн өңнүг чүве.

Маны даштар хайыргалап, сиилбип

каан

Мага-бодум күдер, мөчек, силиг,

чараш.

Аткан даңның херелинге солаңгылап,

Алмаз, дойлу шуру шуудуп ойнай бээр

мен ${ }^{1}$.
Я водопад.

И как радуги цвет мое сердце,

Краски мира живут там все вместе.

И гранитные камни меня, и мрамор точили,

Вот и тело мое совершенно, чисто,

всесильно.

И в лучах восходящего солнца ярким

огнем,

Зажигаю алмаза оттенки в сердце

своем.

Лирический субъект тувинского поэта является, с одной стороны, носителем обобщенно-личного сознания - родового сознания людей, связывающих свое происхождение с природными стихиями, с другой - индивидуального сознания человека, размышляющего об особенностях своего характера и отождествляющего себя с динамичной, изменчивой, контрструктурной стихией воды и свойственным ей мотивом безостановочного движения, в котором - дух и энергия неиссякаемого порыва к цели, преодоления преград: «Оккур, мөге, дошкун, дөспес адым алгаан / Оожургал-дыш черле билбес амытан мен» ${ }^{2}$ («Так поток мой мощный суровый, не зная преград, / Беспокойно все рвется вперед, ведь я - водопад»).

В отличие от лирического субъекта И. Юзеева «я» А. Уержаа не только отождествляется с водопадом, но и превращается в него, одушевляя и одухотворяя водный поток - становясь мечтаньем «родникаручейка», «сном-воспоминанием» всех морей. Здесь происходит «осознанное расширение этнически мотивированного горизонта» (Султанов, 2008: 345).

Вместе с тем тувинский поэт запечатлел и обратный процесс - переход природного в физическивитальную сферу человеческой экзистенции: от водопада к лирическому герою переходят жизненная сила и непреклонность воли:

Үерлигде, тыртыңда-даа серип болбас,

Үүле-чолум амыр эвес, дошкун болгаш,

Арыг-кылаң меңги суундан хөөнүн тыпкан

Аян-ырым авыяас чок, өткүт, сүрлүг³.
И в наводненье, и в маловодье не прерываясь, Как стрела я лечу, к судьбе непростой привыкая.

Оттого, что беру я начало у ледников, Так же чист мой голос пронзительный, так же суров.

В «определениях» оба поэта используют «биноминативные» синтаксические конструкции, выражающие идентификацию. В ряде других стихотворений: «Что я наделал?» (в переводе Р. Кожевниковой: «Что со мной?») И. Юзеева и «Костры лиц, у которых я согревался» А. Уержаа используется диалогическая форма - разговор лирического героя с самим собой. Осмысление переломного момента жизни с точки зрения своего участия и неучастия в нем, активности и страдательности оказывается порождающим началом как субъектной, так и образной структуры стихотворения.

${ }^{1}$ Уержаа А. К. Ынак-тыр мен...: Шүлүктер, шүлүглелдер, чечен чугаалар [Я люблю... : Стихи, поэмы, рассказы]. Кызыл: Тувинское книжное издательство, 1997. С. 75. (На тув. яз.).

${ }^{2}$ Там же.

${ }^{3}$ Там же. 
В стихотворении татарского поэта превращение необузданного жеребенка, не знающего предела своим мечтам, в ломовую лошадь, тянущую бремя времени, отражает метаморфозу, произошедшую с «я»: «Что со мной? / Жеребенком вольным я был, /Упоенный мечтой. <...> Что со мной? / Я тяну бремя времени / Лошадью ломовой» ${ }^{1}$.

Внутринаходимое действующее лицо бытийной ситуации - чувства, названные «бурными волнами юности» («яшьлегемнең шаян дулкыннары»):

\author{
Нишләдем? \\ Мин йөгәнсез чапкан бер тай идем, \\ Белми идем хыял чикләрен. \\ $<\ldots>$ \\ Нишләдем? \\ Юрга тайдай түгел, йөк атыдай \\ Тартып барам заман йөкләрен ${ }^{2}$.
}

\author{
Что со мной? \\ Выплескивались чувства мои, \\ Не умещаясь в клетке грудной. \\ $<\ldots>$ \\ Что со мной? \\ Юности бурные волны \\ Запер я в клетке грудной.
}

Изображаемые действия имеют нелокальный и временной характер, они оказываются равнопротяженными жизни. Их жизнеохватывающая длительность воплощена в сюжетном движении, основу которого составляет переход от обратной перспективы, т. е. интенции, идущей от чувств («выплескивались»), к прямой - усилиям «я», направленным на то, чтобы вернуть чувства в прежнее пространство, замкнутое и безысходное 3 . Таким образом, прямая перспектива, страдательная позиция чувств, «запертых» в тесный и узкий локус, - такова «действительность» лирического героя. Но это еще и момент, в который он перестает узнавать себя: «Нишләдем?» («Что я наделал?» или «Что со мной?»). Этот вопрос является структурно-семантическим центром, организующим композицию стихотворения и определяющим его архитектонику. Предположение: «Тупасланганмы әллә хисләрем?» (дословно: «Огрубели ли чувства мои?») - не объясняет произошедших изменений, а лишь вызывает воспоминания:

Йөрәгемне салып күрегенә,

Гармун уйный идем кичләрен ${ }^{4}$.
На гармони играл я весной, Душу в нее вдохнув.

Все в стихотворении помимо этого нового душевного состояния «я» названо, неназванным остается только оно. Попыткой определить его, ответить на вопрос: «Что со мной?», становится высвобождение чувств, охваченных стремлением преодолеть свою имманентность по отношению к «я», выйти во вне, «оплотнеть» ${ }^{5}$ в бытии, став в соответствии со своей текучей, изменчивой, стихийной природой «шальными волнами»:

\footnotetext{
${ }^{1}$ Современная татарская поэзия / перевод с татарского; сост. Л. Газизова, С. Малышев. Казань: Татар. кн. из-во, 2008. C. 447.

${ }^{2}$ Юзеев И. Мәңге ян, күңел: шигырьләр, жырлар, балладалар, поэма [Душа, гори вечно: стихи, песни, баллады, поэма]. Казан: Татар. кит. нәшр., 2012. С. 69. (На татар. яз.).

${ }^{3}$ Возникает аллюзия на стихотворение Г. Тукая «Өзелгән өмид» («Разбитая надежда», 1910), в котором метафора «клетки мира», тесного, ограниченного пространства, противопоставлена «птице души», устремляющейся вверх, в сферу возвышенного.

${ }^{4}$ Юзеев И. Мәңге ян, күңел: шигырьләр, жырлар, балладалар, поэма [Душа, гори вечно: стихи, песни, баллады, поэма]. Казан: Татар. кит. нәшр., 2012. С. 69. (На татар. яз.).

${ }^{5}$ Термин М. М. Бахтина (см.: Бахтин, 2003: 205).
} 
Нишләдем?

Давылламый, эчтә ташый хәзер

Сабырланган яшьлек хисләрем.

Нишләрем -

Күкрәгемне ватып чыкса әгәр

Сыешалмый яткан көчләрем?

Яшьлегемнең шаян дулкыннары

Шашып әйтсә миңа:

«Нишләдең?!»1
Что со мной?

Юности чувства

Ропщут теперь в груди.

Что впереди?

Что, если чувств

Волны шальные,

Презрев покой,

Вырвавшись, спросят:

“Что с тобой?"

В стихотворении А. Уержаа «Чыннып алган шырайларым одаглары» («Костры лиц, у которых я согревался») осознание лирическим героем неразрывной связи с другими людьми и народом в целом дает возможность заглянуть в свой внутренний мир, раскрывая авторское сознание в «субъектных формах выражения» (Власенко, 1995: 17). Чувство признательности всем, кто дарил ему свое душевное тепло, во многом определяет и выявляет его образ - образ человека благодарного и совестливого, осознающего всеобщую взаимозависимость всех со всеми:

Ээр-дагыр оруктарга чортуп чорааш,

Эвээш эвес сеткилдерге өртээлдедим.

Чыннып алган шырайларым одаглары

Чылдар өттүр чырывышаан турган

ышкаш².
Я во многих душах на ночлег

$$
\text { оставался, }
$$

По дорогам извилистым путь свой торя,

А костры же тех лиц, чьим теплом согревался,

До сих пор сквозь все годы горят и горят.

Здесь особо выделяется образ одинокого путника, в душе которого все еще горят костры, у которых он грелся. Создается контраст между степью, равнодушно взирающей на звёзды, и лирическим «я», перебирающим чётки имен:

Салым-чолдуң чашканнап каан сылдыстарын

Сарыг хову чоомча чокка кайгап чыдар.

Аттарыңар эрегезин шууда тудуп, Ам-на харын хая көрнүп, доктаай бердим ${ }^{3}$.
Эта желтая степь равнодушно взирает

На творенье судьбы - россыпь звезд над собой.

А я, четки ваших имен перебирая, Оглянулся назад и застыл сам не свой.

Как и лирический герой И. Юзеева, «я» в стихотворении А. Уержаа переходит с внутренней точки зрения на внешнюю, прямая перспектива уступает место обратной. У татарского поэта рефрен: «Что

${ }^{1}$ Юзеев И. Мәңге ян, күңел: шигырьләр, жырлар, балладалар, поэма [Душа, гори вечно: стихи, песни, баллады, поэма]. Казан: Татар. кит. нәшр., 2012. С. 69. (На татар. яз.).

${ }^{2}$ Уержаа А. К. Ынак-тыр мен...: Шүлүктер, шүлүглелдер, чечен чугаалар [Я люблю... : Стихи, поэмы, рассказы].

Кызыл: Тувинское книжное издательство, 1997. С. 118. (На тув. яз.).

${ }^{3}$ Там же. 
я наделал?», трансформируется в вопрос: «Что ты наделал?», который адресуют лирическому герою его чувства и который выступает своеобразным авторефлексивным жестом отстранения субъекта речи от самого себя. Аналогичную функцию в стихотворении тувинского поэта выполняет охватившее лирического героя чувство вины:

$$
\begin{gathered}
\text { Ынаныштың, бүзүрелдиң ишкир хавын } \\
\text { Ыят болуп, дүптеп берип шыдавайн, } \\
\text { Каңдаан шөлдү ыскарып каан } \\
\text { дымырааш дег, } \\
\text { Кажыңарны хомудаттым?.. Буруум } \\
\text { улуг }{ }^{1} .
\end{gathered}
$$

В вашей веры в меня и доверия торбы

Мало что положил в возмещенье затрат.

Словно в засуху дождик короткий притворный,

Скольких так я обидел?.. Как я

виноват!

В стихотворении И. Юзеева чувства обретают автономную от «я» жизненную силу. Их экстатический порыв сопровождается утратой земной идентичности - разрушением физической субстанции человека (дословно: «Что буду делать - / Если силы, не умещающиеся в грудной клетке, / разбив ее, выйдут?»). Таким образом, лирический субъект претерпевает изменение строя своей субъективности, обнаруживая несоответствие физически-телесных границ своего «я» и преодолевающего их экзистенциально-эмоционального начала.

А лирический герой А. Уержаа, выступающий одновременно в двух ипостасях: субъекта и объекта, действующего и испытывающего воздействие, переживает катарсическое перерождение, которое сопровождается выходом в творческое измерение бытия: «Чыннып алган шырайларым одаглары, / Чырыыңарга харыылаар дээш кызып чор мен...» («О, костры милых лиц, где пришлось мне погреться, / Я старюсь в ответ спеть вам песню огня...»).

Таким образом в лирике И. Юзеева и А. Уержаа отразилась одна из важнейших тенденций историко-литературного процесса - преодоление границ между субъектом и объектом, видение мира как проекции авторского «я». Здесь лирический субъект предстает как неповторимо-личное «я», связанное с «другим», с «мы», не совпадающее с собой и т. д. Вместе с тем этот субъект выступает и как носитель родового сознания народа, нации, человечества, как «я», равнозначное природнокосмическому универсуму, пристально вглядывающееся в границы не только «я» и «другого», но и «я» и мира. В этом плане художественные поиски татарского и тувинского поэтов отражают укрупнение масштабов лирического субъекта, разрушающее его иерархическую соизмеримость с космосом и устанавливающее между ними прямые отношения. От конкретного и индивидуального «я» классической поэзии его отличает синкретичность, несовпадение с самим собой, равновеликость мирозданию, замещаемость объективированными и отчуждаемыми вовне субститутами.

\section{Вероятностно-множественное «я» Р. Ахметзянова и А. Даржая}

Художественные системы Р. Ахметзянова ${ }^{3}$ и А. Даржая ${ }^{3}$ отражают пути самоопределения лирического героя, обладающего способностью смотреть на себя и на «другого» с разных сторон. Предметом жизненно-эстетического переживания становятся как ситуации самоценности и самостоятельности «я» и «другого», диалогической соотнесенности их кругозоров, так и состояние их синкретической нераздельности, возможности переходов с одной позиции на другую. Природа и родная земля вос-

\footnotetext{
${ }^{1}$ Уержаа А. К. Ынак-тыр мен...: Шүлүктер, шүлүглелдер, чечен чугаалар [Я люблю... : Стихи, поэмы, рассказы]. Кызыл: Тувинское книжное издательство, 1997. С. 118. (На тув. яз.).

${ }^{2}$ Там же.

${ }^{3}$ Ахметзянов Роберт Валеевич (1935-2008) - Заслуженный деятель искусств Республики Татарстан, лауреат Государственной премии РТ им. Г. Тукая. Родился в с. Рыбная Слобода Республики Татарстан. Автор 20 сборников поэзии.

${ }^{4}$ Даржай Александр Александрович (1944-2016) - Народный писатель Республики Тыва, лауреат Государственной премии Тувы им. С. А. Сарыг-оола. Родился в с. Суг-Аксы Сут-Хольского района Тувинской автономной области. Автор более 30 книг.
} 
принимаются как области дорефлексивной целостности, но перестают быть объектом изображения, приобретая признаки субъекта, с которым у лирического «я» устанавливаются особые отношения.

Разным формам субъектной организации и разным типам субъектов в лирике Р. Ахметзянова соответствуют образные языки параллелизма, тропов и «простого» слова. Ориентированные друг на друга и находящиеся в эстетических отношениях взаимоосвещения, они создают вероятностно-множественную модель мира, статуса субъекта и его судьбы.

Наиболее распространенный тип субъектно-образных ситуаций в лирике Р. Ахметзянова связан с заложенными в художественной целостности его произведений возможностями косвенного представления субъекта, которые предполагают, что он не только на себя смотрит как на «другого» - как на «ты», но «другого» воспринимает как себя - как «я». Эта тенденция проявилась в стихотворениях «Жәяүле күбәләк» («Пешая бабочка»), «Гомер тирәге ${ }^{1} »$ («Древо жизни»), «Бәхеткә барыр юлларның» («На дорогах, ведущих к счастью») и др. Выделенной особенности субъектной сферы соответствуют символические формы и иносказательный сюжет. Риторическое развертывание темы определяется не только переходом от внешнего (природного) к внутреннему (человеческому) плану, но и их смешением и формированием синкретической образности.

Рассмотрим в качестве примера миниатюру «Пешая бабочка». Первые строки в ней посвящены «нашей» тоске и «нашим» стремлениям:

Безнең сагыну шундый -

ашкынабыз жир үзәге булган төбәккә,

йөрәгебез

болытларга тигәләп! ${ }^{2}$
Мы тоскуем,

стремясь к центру мира,

сердцами

облаков касаясь!

Далее взгляд движется сверху вниз: от облаков - к горам и лесам. Дается конкретная и крупным планом увиденная картина перемещения через пространство, расширяющееся в горизонтальной проекции:

Ә түбәндә

таулар, урманнар артына

чакырымнар аша

жилне жиңеп, жилфер-жилфер килеп,

кайта

бер күбәләк!

Кайта! ${ }^{3}$
А внизу, пролетая над горами и лесами, трепеща на ветру, преодолевая его силу, возвращается бабочка!

Возвращается!

Значимой в структуризации горизонтального пути является идея преодоления трудностей и преград. Она реализуется в комплексе образов, отмеченных акустическими и кинетическими процессами и действиями. Интенсивная динамика активного волеизъявления в начале пути взаимодействует с внутренним эмоциональным напряжением, возникающим на самом опасном участке пути, в противостоянии стихийной силе ветра. Эти строки изобилуют звуковой инструментовкой. Монотония гласных звуков «а», «у» («таулар, урманнар артына...») и вторящих им согласных «р», «н» сменяется драматическим противостоянием гласных «и», «е» («жилне жиңеп, жилфер-жилфер...») и согласных «ж», «ф», интонационно затормаживающих темпоритм контекста.

Путь выстраивается по принципу наращивания преград: возможность его пройти ставится под угрозу встречным хаотическим движением листьев, летящих со всех сторон: сверху (из-под облаков), снизу (с тропинок), изнутри (из глубины лесов):

${ }^{1}$ Дословно: тирәк - тополь.

${ }^{2}$ Әхмәтжанов Р. Хәтер елгасы. Шигырьләр, балладалар, поэмалар [Река памяти. Стихи, баллады, поэмы]. Казан:

Тат. кит. нәшр., 1980. С. 130. (На татар. яз.).

${ }^{3}$ Там же. 


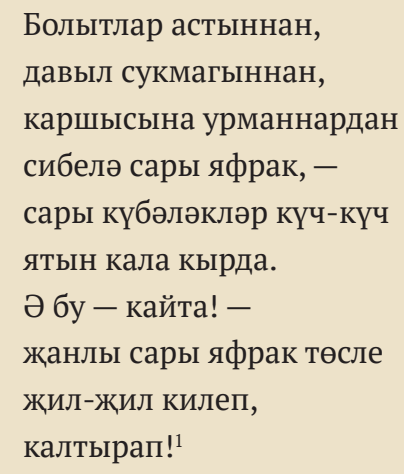

Из-под облаков, из тропинок, застланных бурей, из глуби лесов летят ей навстречу ворохи листьев желтых, такой же желтой листвой другие бабочки гибнут и застилают поля. А она продолжает путь! возвращается куда-то...

Анархический натиск и иррациональная динамика этого противотечения-кружения оказываются губительными - ведут к спутыванию и смешению бабочек и листьев - одушевленного и неодушевленного, живого и мертвого. Но бабочка побеждает и в этом максимально трудном и исполненном риска поединке с враждебными стихиями благодаря телеологичности своего пути.

Образ бабочки, не прикрепленной к определенному локусу, находящейся в состоянии безостановочного движения и борьбы с препятствиями, воплощает дух и энергию неиссякаемого порыва к цели:

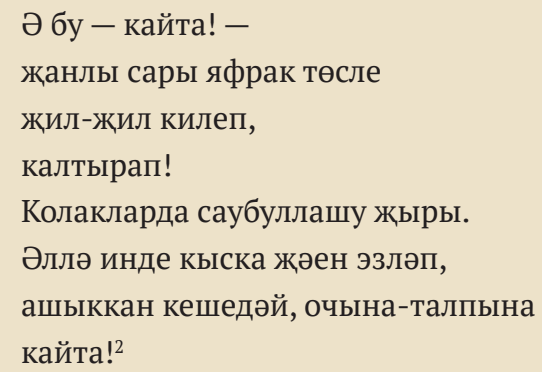

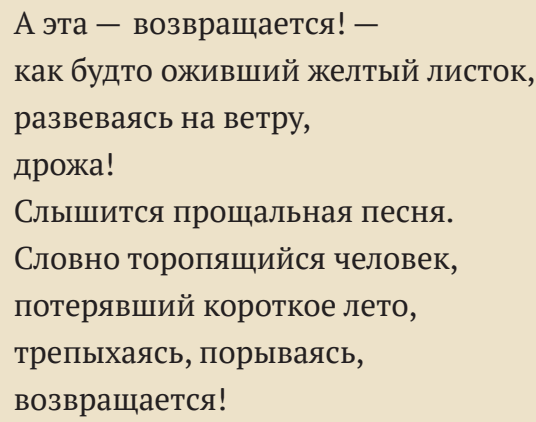

Между бабочкой, желтым листом и человеком, потерявшим короткое лето, возникает такая же связь, как между листьями, птицами и «нашим» летом в стихотворении «Көндәлектән (Өзелеп калган көн)» («Из дневника (Прерванный день)») - не только метафорическая, но и субстанциональная (Аминева, 2016: 283). В финале формулируется итог этих мифологических метаморфоз: пешая бабочка отождествляется с душой летних лугов: «Душа летних лугов - пешая бабочка».

Субъекты соположения, образующие кумулятивный ряд, объединенный семантикой возвращения, создают одну синкретическую реальность. Между возвращающейся бабочкой, человеком, ищущим свое короткое лето, и душой летних лугов устанавливается не только условно-поэтическое сходство, но и субстанциальная неразделенность. На примере истории бабочки рассказывается история души, одержимой идеей возвращения - к самой себе, к истокам и первоосновам собственного бытия (в свое «короткое лето»), в родное пространство. Это почти чистый порыв, самодостаточный и неодолимый, как зов природы. Сливаясь с бабочкой в естественности своего желания, «душа лугов» вместе с тем обнаруживает в себе отсутствие главного качества - способности летать.

Сходная субъектно-образная ситуация возникает в ряде стихотворений известного тувинского поэта А. Даржая: «Шак ол мен мен» («То буду я»), «Өртемчейге чурттап чорааш...» («Живя на белом свете...»), «Дамырак» («Ручеек»), «Кежээки бодал» («Вечерняя мысль») и др.

\footnotetext{
${ }^{1}$ Әхмәтжанов Р. Хәтер елгасы. Шигырьләр, балладалар, поэмалар [Река памяти. Стихи, баллады, поэмы]. Казан: Тат. кит. нәшр., 1980. С. 130. (На татар. яз.).

${ }^{2}$ Там же.
} 
Поэзия А. Даржая отличается аутентичностью мотивов, образов и лексического строя, подлинно национальным духом. Одним из вариантов ответа на вопрос «Кто я?» может считаться его стихотворение «Шак ол мен мен» («То буду я»). В ней он видит себя седым стариком, вспоминающим свое прошлое, сидя на околице вечерней зарей:

Дүн дег кара, сырый башка хыраа дүшкен

Дүвүрел чок, даянгыыштыг кырган кижи

Кызыл-даван маңнап өскен черин эргип,

Кызыл-хүнде чанып келир: шак ол мен мен $^{1}$.
На склоне дня, на склоне дня седойседой

Пойдет к околице старик, взяв посох свой,

Пойдет вечернею зарей взглянуть в луга,

Где бегал некогда босой, - то буду я» (Пер. А. Смольникова) $)^{2}$;

«босым мальчонкой», бегавшим здесь на лугу и добывавшим в горах хая-чугу - мумиё для заболевшей матери; влюбленным юношей, поджидавшим здесь свою черноокую; зрелым мужчиной, который, хоть и не совершил подвиг в бою, зато посадил ряд тополей и «прожил честно меж людей». Все стихотворение проникнуто воспеванием простых, но вечных ценностей, придающих жизни человека подлинный и высокий смысл. И, глядя на вечернюю зарю, лирический герой, обнимает внука, воспринимая его как свой рассвет:

Чурттуң каазын чарашсынып кайгап ора,

Чуртталганың төнчү чогун херечилээн

Төлүнүң чаш хензиг оглун кырган

кижи

Дөңмээн орта олуртуптар: шак ол мен мен $^{3}$.
Налюбовавшись красотой зари ночной,

Он снова мыслью обоймет свой век земной,

Обнимет внука, потеплев: «Вот мой рассвет!

Род мой на свете не умрет!» - то буду

я.

Образная система стихотворения строится не на тропеическом ${ }^{4}$ принципе, а на параллельных уподоблениях, репрезентирующих этапы жизненного путичеловека. Характерноедля рационального сознания линейное мышление переходит в мышление, имеющее концентрическую структуру: быстротечность человеческой жизни, необратимость происходящих изменений уравновешиваются представлением о вечном возвращении и непрерывном обновлении мира. Оно устанавливает и закрепляет связи «я» с окружающим, близким и отдаленным, общим, стирает пределы свершившегося и возможного, осуществляя прорыв в иной мир и приобретая искупительную телеологию циклического мирового времени. Вероятностно-множественное «я» в лирике А. Даржая восходит к своеобразно понятой идее «пути» как «непрерывной возможности изменений и превращений» (Григорьева, 1982: 161).

Таким образом, в поэзии Р. Ахметзянова и А. Даржая все, что отделяется от «я» и на что можно посмотреть со стороны как на «другого», приводит к пониманию неких необъективируемых и истинных начал, которые проявляются всей субъектно-образной системой стихотворений.

\footnotetext{
1 Даржай А. А. Чогаалдар чыындызы: Шүлүктер, шүлүглелдер [Собрание сочинений: Стихи, поэмы]. Кызыл: Тувинское книжное издательство, 1994. С. 40. (На тув. яз.).

2 Даржай А. А. Избранное. Поэзия и проза. Кызыл: Тываполиграф, 2016. С. 25.

3 Даржай А. А. Чогаалдар чыындызы: ... С. 40.

${ }^{4}$ Один из образных языков лирики, основанный на использовании тропов, т. е. слов, имеющих переносное значение.
} 


\section{Обращенность «я» к стихиям жизни, любви и творчества (Р. Ахметзянов, Э. Мижит, Р. Гаташ, А. Уержаа, Н. Куулар)}

Специфика субъектно-образной целостности лирики татарских и тувинских поэтов раскрывается и в отношениях «я» с субъектами особого типа, точнее - сверхсубъектами, воплощающими надличностное и вненаходимое по отношению к основной лирической ситуации и ее героям активно-волевое начало.

В лирике Р. Ахметзянова в качестве некой внеличной самостоятельной силы, выступающей по отношению к лирическому субъекту одновременно и как внешнее, и как внутреннее, как имманентное ему и как трансцендентное начало, выступает летняя природа. Лирический субъект стихотворения «Июнь иле» («Страна Июня») возводит истоки своего «я» к Июню как особому дорефлексивному райскому состоянию мира. Летний пейзаж, как высшее пластическое, звуковое и цветовое выражение красоты и упорядоченности, открывает Космос, живущий по своим законам и осуществляющий свой смысл в соответствии с высокой целью - гармонического соединения неба и земли, горизонтали и вертикали, солнца и реки, ветра и листьев. Взаимоотношения разных сфер и стихий бытия определяются направлением их встречного движения. Знаками смешения, снятия оппозиций являются образы одуванчиков, сверкающей реки, улыбки солнца на ее берегу:

“Очам!” диеп тора тузганаклар шары.

$<\ldots>$

Кояш елмаюы -

яшел яр читендә,

балкып тора елга

яшел рам эчендә!1
“Полечу!” - говорит одуванчика шар.

$<\ldots>$

Улыбка солнца -

на краю зеленого берега,

сияет река

в зеленой раме!

Говорящий не только смотрит на страну Июня с «внежизненно активной точки зрения» ${ }^{2}$, позволяющей осознать ее самоценность, но и отстраняет от себя свое детство, персонифицируя его в образе «другого» - ребенка, сопричастного окружающему миру природы. В стихотворение входит образ времени, измеряемого и абстрактным количеством («Лесные часы бьют двенадцать...), и природными ритмами («“А-у!” - я отвечаю через тридцать июней»), и историческими событиями («Война - давно прошла!»). Лирический герой находится в двух временных точках (в прошлом и настоящем), занимая по отношению к ним сложную позицию - переступает из одной в другую и старается соединить их. Поиск утраченного времени и попытка вернуть двенадцатилетнего мальчика в настоящее сопровождается рядом субъектных метаморфоз.

Пережитые в детстве душевные состояния вспоминаются и получают смысл, недоступный «я» в утраченном тогда и обретенном теперь времени. В первую очередь это относится к игровому модусу бытия, преодолевающему преграды, которые сковывают поведение человека в серьезном мире, и дающему экстатическое чувство жизни: «Буду водить тебя по магазинам (не шучу), / выбирай все, что душа пожелает! / Брось деревянную лошадь, / игрушек - бесчисленное множество! / Назло тому времени / вдоволь наиграйся... ау... у!». Иронический тон, обращенный на себя, является следствием того, что говорящий учитывает интенцию своего двойника - ребенка. Высказывание «я», адресованное к мальчику, оставшемуся «там», всем своим ритмико-интонационным и лексико-стилистическим строем снимает временную дистанцию между ними.

В этот, казалось бы, миг обретенного времени лирический субъект переступает в реальное настоящее, в котором происходит превращение мальчика в «сына леса», «моего детства» - в страну Июня. Реализуется мифологическая по своей модальности ситуация, требующая не условно-поэтического, а субстанциального понимания. Перед нами - картина любовного служения, разворачивающаяся в последовательной смене образов. Природа переживает редкий исключительный момент ожидания жениха: «Трава - по пояс, / хор бабочек. /У природы / время ожидания жениха...». Двойник лирического

${ }^{1}$ Әхмәтжанов Р. Хәтер елгасы. Шигырьләр, балладалар, поэмалар [Река памяти. Стихи, баллады, поэмы]. Казан: Тат. кит. нәшр., 1980. С. 54. (На татар. яз.).

${ }^{2}$ Понятие, введенное М. М. Бахтиным (Бахтин, 1986а: 9-191). 
героя не откликается на призыв вернуться и отказывается от внешнего движения, но эта остановка состояние любовного единения с летней природой:

Шау үләннәр кочып, жәеп ике кулын, гашыйк күзләр белән ята урман угылы...
Обняв шумящие травы, раскинув руки,

лежит

сын леса

с влюбленными глазами...

С преображением мальчика в сына леса, указывающем на природную родословную лирического субъекта, меняет свою модальность и страна Июня: оставаясь временем года, она трансформируется в детство лирического героя:

Июнь жиле исә

үләннәрне тарап...

Ята бала чагым

кошлар юлына карап².
Веет июньский ветер,

приглаживая травы...

Лежит мое детство,

провожая взглядом улетающих вдаль

птиц.

Образно-смысловая связь летнего пейзажа и «моего детства» не только снимает границу между природой и человеком, прошлым и настоящим, но и синкретически смешивает их. Образное соположение говорит о длящемся и до сих пор ощущаемом бытийном единстве детства и июня, но одновременно и о выходе «я» из этого «райского» состояния: «Заворожен небом, / даже не дышит... / И не зови - / не вернется. / Он счастлив - / там!» Нецентрированное наложение друг на друга двух временных пластов сменяется дистанцированием от этого дорефлексивного бытия и осознанием необратимости текущего времени. Герой возвращается в мир пространственной вертикали, а детство, оставленное «там», лишается активности, динамичности, оставаясь неподвижным в мире, смещенном горизонтально.

В лирике Э. Мижита ${ }^{3}$ чертами сверхсубъекта, обладающего постулируемой самостоятельностью, наделяются «корни», к осмыслению многосторонних связей с которыми устремлена лирико-философская мысль поэта. В верлибре «Корни мои» глубоко личные мотивы и образы сплавлены воедино с образами бесконечной вселенной и бесконечного времени. В одном сочинительно-перечислительном ряду оказываются капли вечных напевов и напиток богов:

Корни мои -

в тех высоких хребтах

с погасшей золой и пеплом,

оставшихся от очагов

моих предков,

\footnotetext{
${ }^{1}$ Әхмәтжанов Р. Хәтер елгасы. Шигырьләр, балладалар, поэмалар [Река памяти. Стихи, баллады, поэмы]. Казан: Тат. кит. нәшр., 1980. С. 56. (На татар. яз.).

${ }^{2}$ Там же.

${ }^{3}$ Мижит Эдуард Баирович (1961) - Народный писатель Республики Тыва, лауреат премии Министерства культуры и кино РТ, заслуженный деятель искусств РТ. Родился в с. Торгалыг Улуг-Хемского района Тувинской АССР. Автор 9 сборников поэзии и драматургии.

${ }^{4}$ Верлибр (фр. vers libre свободный стих) - стихотворение, строящееся на интонационно-синтаксической основе, не связанной ни рифмой, ни определенной метрикой.
} 
и в тех вечных напевах,

по каплям вливавшихся в мою душу

из уст моей матери,

словно некий напиток богов ${ }^{1}$;

безмерность мира и крохотное сердце, вместившее его в себя:

Корни мои -

в том самом мгновеньи,

когда я

совсем еще ребенком

впервые осознал

всю безмерность этого мира,

и эта безмерность

каким-то чудом

угнездилась, как птенчик,

в моем крохотном

сердце ${ }^{2}$;

маленький сын и улетающие птицы как символ и скоротечности, и бесконечной повторяемости жизни и времени; глаза любимой, звездное небо, земля, сердцевина жизни и т. д.:

Корни мои

вросли

в это звездное небо,

в эту землю

и сердцевину жизни,

где бьют самые чистые

и сокровенные

источники бытия ${ }^{3}$.

Символика корней проявляет характерную для данной национальной традиции связь «я» с «самыми чистыми и сокровенными источниками бытия» как сферой внеличного, переходящего и становящегося личным. В финале стихотворения вырисовывается космический образ человека, сравнимого с мифологическим мировым древом, являющимся осью Вселенной: «...И не так-то легко / вырвать меня с корнем / из этого мира, / не причинив ему / боли». Все вышеперечисленные поэтические образы занимают позицию вненаходимости и внежизненной активности по отношению к миру «я». Возникающей субъектной ситуации соответствуют мифопоэтические «языки» кумуляции и параллелизма.

Несколько иная тенденция выражена в стихотворении Э. Мижита «Бездна». Определяя себя через свое отношение к миру, лирический герой поэта, наряду с глубоко личными и национальными образами, использует наднациональные, общечеловеческие образы и мотивы:

Не все перебираются

через топкую чащу тайги -

кто-то попадает не на ту тропу

в ее лабиринте,

и они,

побуждая идущих

теснее сбиться в кучу,

исчезают в бездне лесов... ${ }^{4}$

\footnotetext{
${ }^{1}$ Мижит Э. Б. Расколотый миг. Кызыл: Тувинское книжное издательство, 2011. С. 21.

${ }^{2}$ Там же. С. 22.

${ }^{3}$ Там же.

${ }^{4}$ Там же. С. 62.
} 
«Я», являясь частью всего человечества, как и все люди, несмотря на все свои удачи и неудачи, взлеты и падения, бессилен перед бездной небытия, в которой он исчезает, «не вызывая ни в ком ни страха, ни удивления»:

Не все доходят до цели.

Не всех успевают спасти.

Но тот,

кто доплыл,

дошел

и дополз,

видит перед собой

всё ту же могильную яму...

О новаторских поисках Э. Мижита и его стремлении раскрывать для читателя сложнейшие философские понятия пишут в своих статьях литературоведы Л. С. Дампилова, А. Л. Кошелева, А. М. Соян, У. А. Донгак, О. А. Валикова, Б. Е. Шагимгиреева, Ш. А. Кулиева (Дампилова, 2014; Кошелева, 2016; Соян, 2018; Донгак, 2020; Валикова, Шагимгиреева, Кулиева, 2020).

В стихотворениях Р. Гаташа ${ }^{2}$ в качестве сверхсубъекта, наделенного бытийной полновесностью и способностью воздействовать на жизнь людей выступает Песня / Мелодия. Так, стихотворение «Уел»³ примыкает к «Милли моңнар» («Национальным мелодиям», 1909) Г. Тукая и развивает заложенные в субъектной архитектонике этого произведения диалогические структуры.

В «Уел» несколько семантических центров, обозначенных как «мы», «много повидавшая восьмидесятилетняя старушка», «песня», «мелодия», «душа народа». Субъект речи обозначен как «мы», будучи носителем обобщенно-личного сознания людей, слушающих исполнение песни «Уел» и объединенных общностью эстетического переживания:

Күпне күргән сиксән яшьлек әби

Бер жырлады безгә «Уел»ны;

Күзләр коры иде, тавышындагы

Яшьләр гүя жанга коелды...4
Бабушка восьмидесяти лет

пела нам «Уел» в тени березы...

Слезы нам не затмевали свет,

но светло вскипали в душах слезы.

(Пер. Р. Бухараева $)$

Слезы, заключенные в голосе исполнительницы песни, проникают в души слушателей, а в последующих строфах превращаются в Историю и в реку Агидель, оказываются равнопротяженными им. Как и в «Национальных мелодиях» Г. Тукая, в «Уел» Р. Гаташа голос одного человека, исполнителя песни, становится голосом целого - «души народа» (халык жаны). Между «я» и «мы» устанавливаются экзистенциальные отношения тождества, единства, взаимопроникновения. Пришедшая издалека печаль, извлеченная из сердца и воплощенная в старинной мелодии, выявляет то, что свойственно внутреннему миру всех представителей этноса, - общее в мировосприятии, жизненной позиции, идейно-эмоциональных реакциях на явления действительности. Родовое сознание людей, размышляющих о судьбе своей страны, сливается с сознанием личности, концентрирующей в своем внутреннем мире эмоционально-психологический опыт «мы» народа.

\footnotetext{
${ }^{1}$ Мижит Э. Б. Расколотый миг. Кызыл: Тувинское книжное издательство, 2011. С. 62.

${ }^{2}$ Радиф Гаташ (Гатауллин Радиф Кашфуллович) (1941) - Заслуженный работник культуры Татарстана, Заслуженный деятель искусств Татарстана, лауреат Государственной премии им. Г. Тукая, литературной премии им. Х. Такташа. Родился в деревне Марс Кушнаренковского района Башкирской АССР. Автор более 20 сборников поэзии.

3 Уел - старинная татарская народная протяжная песня.

${ }^{4}$ Гаташ Р. К. Сайланма әсәрләр [Избранные произведения]: 3 т. Казан: Татар. кит. нәшр., 2009. Т. 2. Шигырьләр, поэмалар [Стихи, поэмы]. Казань: Татар. кн. изд-во, 2009. С. 18. (На татар. яз.).

${ }^{5}$ Гатауллин Р. К. Сороковая весна: Стихи и поэмы / пер. с татарск. М.: Современник, 1985. С. 9.
} 
В песне, как в форме своего инобытия, прошлое оказывается не только свершившимся, но и совершающимся, вновь оживающим перед духовным взором слушателей:

Жилләр исте... Батыр ирләр үтте,

Илләр үтте кичеп уемнан;

Ил язмышы йөрәкләргә безнең

«Уел»лары белән уелган.

Бар булганы белән халык жаны

Яшеренгән шушы моңнарга... ${ }^{1}$
Слушал я - и сильные ветра

душу мне пронизывали,

словно

древняя суровая пора

вновь пришла и захватила кровно;

растекалась музыка, как дым

под осенней синью небосвода,

всем извечным существом своим

нам отозвалась душа народа... ${ }^{2}$

Лирическое «я», «мы», старушка, исполняющая старинную песню, «душа народа», сохранившаяся в ней, - все они образуют субъектную целостность, главными чертами которой являются нераздельность и их взаимопереходы «я» в «мы», «я» в «другого», «я» в «душу народа». Субъектный синкретизм перерастает в образный. Поток песни-времени-истории-реки течет в едином русле конкретных человеческих судеб, связывая минувшее, настоящее и будущее и формируя подвижную реальность народно-исторического бытия. Старинная мелодия, живущая в сокровенных тайниках души каждого и имеющая межличностную природу, не исчезает, сопрягая внутренний мир человека с областью универсального и вечного и обеспечивая поступательное движение истории. Осмысление тех отношений, которые связывают духовные ориентиры личности с константами национально-исторической жизни, определяет меру самосознания лирического субъекта, пути его самоидентификации. В финале стихотворения говорящий переходит с внутренней точки зрения на внешнюю и из «мы-я» становится неопределенным лицом (в переводе, выполненном Р. Бухараевым, эта особенность оригинала не сохраняется, используется форма «мы»). Достигнутое дистанцирование от субъекта речи - обозначение внутренней границы между героем и автором.

В стихотворении А. Уержаа «Ынак-тыр мен...» («Я люблю...») судьба личности воссоздается в ее соотнесенности с природно-национальными основами бытия. Выражая свое отношение к миру, а именно глубокую и безграничную любовь к нему, лирический герой приоткрывает завесу и в область своих мыслей и чувств:

Ынак-тыр мен... Өртемчейде

Чүрээмге чоок, эргим төрел

ЧүҮ-ле бар-дыр, сувуразын

Ырлап чор мен - ынак-тыр мен³.
Я люблю в бесконечной Вселенной

$\mathrm{Bce}$, что близко мне сердцу, что дорого мне, Все, что есть, всей любовью безмерной, Прославляю я песней своей все нежней.

Глубоко прочувствованное и взволнованное перечисление образов всего того, что любит лирический герой, создает структуры, отличительной особенностью которых является их «открытость» и «перетекаемость» друг в друга:

${ }^{1}$ Гаташ Р. К. Сайланма әсәрләр [Избранные произведения]: 3 т. Казан: Татар. кит. нәшр., 2009. Т. 2. Шигырьләр, поэмалар [Стихи, поэмы]. Казань: Татар. кн. изд-во, 2009. С. 18. (На татар. яз.).

${ }^{2}$ Гатауллин Р. К. Сороковая весна: Стихи и поэмы / пер. с татарск. М.: Современник, 1985. С. 10.

3 Уержаа А. К. Ынак-тыр мен...: Шүлүктер, шүлүглелдер, чечен чугаалар [Я люблю... : Стихи, поэмы, рассказы]. Кызыл: Тувинское книжное издательство, 1997. С. 5. 
Эрткен өйге, келир үеэ, Назы билбес ынакшылга, Найыралга, актыг шынга, Эки ырга, ээлдек сөске Ынак-тыр мен - йөрээп чор мен ${ }^{1}$.
И прошлое все, и грядущие времена, И любовь, что не знает тяжести лет, И дружбу, и честь, и правду, что вечно верна, И песню, и слово, что дарят нам свет, $-$

Я люблю и навеки благословляю.

Также стараясь самоопределиться через образы родины и любимых людей, Э. Мижит идет несколько другим путем. Переосмысливая некоторые расхожие выражения, которыми определяют Туву, он в верлибре «Место, где Бог» выстраивает линию личных взаимоотношений с родиной. Например, «колыбель народов» и «колыбельная песня мамы»; «загадка», «загадочная Тува» и «тайна», «таинственный звук»; «ничего не помнящая древность» и «сундук снов и мечтаний»:

Говорят, что ты -

колыбель народов, но для меня ты -

моя колыбель,

и колыбельная песня мамы моей, отзвук которой так ясно слышен

в смехе моей дочурки ${ }^{2}$.

...

Говорят, что ты

проста, как загадка,

но для меня ты -

таинственный звук каргыраа ${ }^{3}$, звук, в котором Небо с Землей ищут друг друга, тоскуя, и встречаются здесь -

в душе человека.

В итоге, данная линия приобретает космические масштабы в строках о географическом центре Азии и центре Земли и Вселенной, через который проходит ось мира:

Говорят, что ты

всего лишь географический центр

Азиатского материка, но для меня ты -

центр Земли и Вселенной, средоточие духа моего древнего народа, Тува моя, ты - то самое место, место, где Бог находит и видит меня насквозь.

\footnotetext{
${ }^{1}$ Уержаа А. К. Ынак-тыр мен...: Шүлүктер, шүлүглелдер, чечен чугаалар [Я люблю... : Стихи, поэмы, рассказы]. Кызыл: Тувинское книжное издательство, 1997. С. 6.

${ }^{2}$ Мижит Э. Б. Расколотый миг. Кызыл: Тувинское книжное издательство, 2011. С. 122.

${ }^{3}$ Стиль горлового пения.
} 
Таким образом, в отличие от бытующего в некоторых национальных литературах образа своей родины как маленького уголка, как окраины большой страны и мира, Э. Мижит впервые в тувинской поэзии определяет свою родину как духовный центр мироздания, в котором «Бог видит его насквозь». В этом выражается его идея о том, что через его сердце, как и через сердца всех людей, проходит духовная ось, связывающая дух и материю, небо и землю, Бога и его творение. Мир для него подобен умозрительной сфере Паскаля (и античных философов), центр которой везде, а окружность - нигде.

Так же, как и А. Уержаа, неотделимой частицей родного народа определяет себя и видный писатель Н. Куулар ${ }^{1}$. «Көшкүн хевээр улус-тур бис» («Мы - все те же кочевники») - восклицает поэт в стихотворении «Сагыжывыс көшкүн хевээр» («Нашим душам снятся кочевья»). Раскрывается образ кочевника - человека, готового в любой момент сложить юрту и отправиться в путь, который, растворяясь в мелькании лет и теряясь в дорогах, бросает взгляд за частокол гор, человека, для которого кочевье - мечта:

\begin{abstract}
Адаларның өскен аалы -
Азий диптиң делгем хөрээ амдыгаа дээр бисти танып, аадып-чайгап аъткарган дег, чагырга чок, хостал күзээр сагыжывыс көшкүн хевээр².
\end{abstract}

Аал, вскормивший отцов

Широкой Азией-грудью,

Скрепивший весь род сетями морщин,

Еще ребенку стелет под ноги дорогу,

Чтобы жить кочевьем - мечтою,

Непокойной, неуловимой.

(Пер. А. Метелькова $)^{3}$

Таким же образом он идентифицирует себя через образы отца и матери, родного дома и природы родного края в стихотворении «Эглип келбес ада-ием...» («Дом родителей моих, покинутый ими...»). В звонком журчании речного переката он слышит голос матери, в шуме горного ветра - голос отца и мечтает так же дать ответ своим потомкам эхом звуков родной стороны, т. е. стать частью всего того, что он любит:

Бодум тыным үстү бээрге, бодалдарым чүглүг хөөнү улузумга улаштырып, ужуп дойлуп дыңналыр боор ${ }^{4}$
Мне бы так же, когда мое время настанет,

Эхом звуков родной стороны

Дать ответ на потомков своих призыванье

Из души и земли глубины.

(Пер. Э. Мижита)

В стихотворении «Сөс» («Слово») Н. Куулар позиционирует себя, как поэта, но не как демиурга, облеченного мистической властью, а как частицу, каплю святого Слова:

\footnotetext{
${ }^{1}$ Куулар Николай Шагдыр-оолович (1958) - Народный писатель Республики Тыва, Заслуженный работник культуры РТ. Родился в с. Торгалыг Овюрского района Тувинской автономной области. Автор 14 книг.

${ }^{2}$ Куулар Н. Ш. Даңгына: Шүлүктер [Принцесса: Стихи]. Кызыл: Тувинское книжное издательство, 1996. С. 6. (На тув. яз.)

${ }^{3}$ Куулар Н. Полночный ветер. Стихи // Сибирские огни. 2014, № 9, сентябрь. С. 115.

${ }^{4}$ Куулар Н. Ш. Чолдуң ному: Шүлүктер, очулгалар [Книга пути: Стихи, переводы]. Кызыл: Тувинское книжное издательство, 2006. С. 9. (На тув. яз.)
} 
Делегейде амылыгны чаяап, тынгарган, делгемнерни, үелерни чыырып, чагырган,

бүгүдениң мурнунда бар турган, бүгүдениң соонда база артар ыдык Сөске кезээде бараалгаан ынай бараскан, хензиг быйыргын мээң үүлем...
Плоть живую сотворившего, дыханье давшего,

Время сжавшего, пространство развернувшего,

Прежде - бывшего

И после - будущего,

Святого Слова невечный паломник я, Ничтожный, почти неуместный.

(Пер. А. Метелькова ${ }^{2}$ )

Он как поэт, «щурится от гордости, слова расставляя», но готов принять, смириться и раствориться в величии Слова: «Покорно судьбе, / Оплакав полет свой недолгий, / Величие Слова принять, / Смириться и раствориться...»³.

Итак, татарские и тувинские поэты, идентифицируя себя как личность, не отделяют себя от своего народа, родины, от мира и вселенной. При всей своей оригинальности и непохожести творческих индивидуальностей, их объединяет чувство единства со своим народом, родиной, природой и миром, мышление о себе как неотделимой части всего этого. Отсюда повторяющийся в разных национальных литературах тип субъектно-образной ситуации, в основе которой — «скользящая» интенция «я», позволяющая ему быть и внутринаходимым действующим лицом в драме существования, и переходить на позицию вненаходимости по отношению к сверхсубъектам, воплощающим внеличное / дорефлексивное сознание, - родной земле, стихиям природы, любви и творчества. Диалог литератур в данном случае подчеркивает семиотическую однородность корреспондирующих текстов татарских и тувинских авторов, выявляет то, что кардинально отличает их от западного типа мышления и сознания, которому свойственен крайний индивидуализм.

\section{Заключение}

В татарской и тувинской поэзии 1970-1990-х гг. складываются сходные типы субъектно-образных структур. В лирике И. Юзеева и А. Уержаа проявления ментального и психического мира лирического субъекта объективируются, превращаются в самостоятельную субстанцию, наделяются своей интенцией и речью. Субъект речи занимает позицию авторефлексивной вненаходимости по отношению к самому себе. Отстранение от «я» - выражение внутренней границы между героем и автором, которая выводит субъектно-образную целостность произведения на уровень метаизображения.

В художественной системе Р. Ахметзянова и А. Даржая «я» оказывается вероятно-множественным, не совпадающим с самим собой, вбирающим в себя интенцию «другого». Создается уникальная ситуация нераздельности «я» и «другого» и вместе с тем пространственной и временной дистанцированности «я» от «ты», «я» нынешнего от «я» прежнего и т. д. В субъектно-образные структуры стихотворений поэтов, представляющих разные национальные традиции, проникает логика мифа: лирический герой совмещает в себе два вида сознания - народно-мифологическое и индивидуально-творческое.

Одним из определяющих компонентов художественного высказывания татарских и тувинских поэтов (Р. Гаташа, Э. Мижита, Н. Куулара) является обращенность их «я» к стихиям жизни, природы, любви и творчества, изображение которых тяготеет к метаморфическому, субстанциальному типу образности. В диалогической обращенности к этому «другому», стоящему за пределами сознания «я», выявляется жизненно-творческая позиция «героя» и «автора». Субъектным ситуациям соответствуют мифопоэтические языки кумуляции и параллелизма.

Вместе с тем сходное в творчестве татарских и тувинских поэтов по форме не является таковым по своей сути, истокам, внутренней природе. Субъектно-образная целостность татарской лирики ре-

\footnotetext{
${ }^{1}$ Куулар Н. Ш. Даңгына: Шүлүктер [Принцесса: Стихи]. Кызыл: Тувинское книжное издательство, 1996. С. 76. (На тув. яз.).

${ }^{2}$ Куулар Н. Полночный ветер. Стихи // Сибирские огни. 2014, № 9, сентябрь. С. 114.

${ }^{3}$ Там же.
} 
презентирует характерные для данного типа культуры ${ }^{1}$ взаимно-однозначные соответствия и взаимопереходы индивидуально-психологического и родового, единичного и единого, конкретного и универсального. Стоит отметить, что в тувинской поэзии действуют несколько иные эстетические закономерности и «процедуры» порождения смысла. Субъект высказывания присутствует в тексте как «я», но это «я» отступает на второй пан и его состояние раскрывается через других - водопад, корни, загадку, Небо и Землю, Слово и т. д. (А. Уержаа, Э. Мижит, Н. Куулар). Между «я» и «не-я» устанавливаются не столько взаимно-однозначные соответствия, сколько отношения взаимовключенности и взаимозамещаемости.

\section{СПИСОК ЛИТЕРАТУРЫ}

Аминева, В. Р. (2016) Не-(пост) классическая картина мира в национальном историко-литературном процессе (на материале лирики Р. Ахметзянова) // Studia Litterarum. Toм 1. № 3-4. С. 278-297.

Бахтин, М. М. (1986а) Эстетика словесного творчества. 2-е изд. М. : Искусство. 445 с.

Бахтин, М. М. (1986b) Проблемы текста в лингвистике, филологии и других гуманитарных науках // Бахтин М. М. Эстетика словесного творчества. 2 изд. М. : Искусство. 445 с. С. 297-325.

Бахтин, М. М. (2003) Собрание сочинений : в 7 т. М. : Русские словари ; Языки славянских культур. Т. 1. 958 с.

Баянов, А. Р. (1985) Гаташ турында [О Р. Гаташе] // Баянов Ә. Заман сурәтләре: лирик язмалар, мәкаләләр, очерклар [Лики времени]. Казан: Татар. кит. нәшр. 271 с. С. 199-230. (На татар. яз.)

Бройтман, С. Н. (1997) Русская лирика XIX - начала XX веков в свете исторической поэтики. Субъектно-образная структура. М. : Российск. гос. гуманит. ун-т. 307 с.

Валикова, О. А., Шагимгиреева, Б. Е., Кулиева, Ш. А. (2020) Космос в логосе: транслингвальная поэзия Эдуарда Мижита и Бахыта Каирбекова // Новые исследования Тувы. № 4. C. 230-249. DOI: www.doi.org/10.25178/nit.2020.4.16

Власенко, Т. Л. (1995) Литература как форма авторского сознания. М. : Наука. 223 с.

Гаджиева, 3. 3. (2015) Жанр исповеди в творчестве аварских поэтов в эпоху «душевного томления» // Вестник института языка, литературы и искусства им. Г. Цадасы. № 8. С. 107-117.

Ганиева, Р. К. (2009) Заманның шигъри пәйгамбәре [Поэтический пророк времени] // Гаташнамә. Рәдиф Гатауллин-Гаташ ижаты турында сәхифәләр. Мәкаләләр, эсселар, шигырьләр [Книга о Гаташе. Страницы о творчестве Р. Гатауллина - Гаташа]. Казань : Дом печати. 439 с. С. 370-377 (На татар. яз.)

Григорьева, Т. П. (1982) Даосская и буддийская модели мира (предварительные заметки) // Дао и даосизм в Китае / отв. ред. Л. С. Васильев, Е. Б. Поршнева. М. : Наука. 289 с. С. 159-179.

Дампилова, Л. С. (2014) Мотив двойничества в поэзии Эдуарда Мижита // Сибирский филологический журнал. № 3. С. 158-163.

Донгак, У. А. (2014) Иволги напев живой: В новом облике древнего слова. Абакан : Журналист. 288 с.

Донгак, У. А. (2020) Новаторство писателя-билингва Эдуарда Мижита (тувинская поэзия) [Электронный ресурс] // Полилингвиальность и транскультурные практики. T. 17. № 4. URL: http://journals.rudn.ru/polylinguality/ issue/view/1367 (дата обращения: 15.12.20). DOI: www.doi.org/10.22363/2618-897X-2020-17-4-4

Дюришин, Д. (1979) Теория сравнительного изучения литературы / пер. со словац. М. : Прогресс. 320 с.

Загидуллина, Д. Ф. (2015) 1960-1980 еллар татар әдәбияты: яңарыш мәйданнары һәм авангард эзләнүләр [Татарская литература 1960-1980 гг.: авангардные поиски и эксперименты]. Казань : Татарск. кн. изд-во. 383 с. (На татар. яз.)

Заһидуллина, Д. Ф., Йосыпова, Н. М. (2011) XX гасыр татар әдәбияты тарихы: дәреслек [Татарская литература XX в.: в 2 кн. Казан : Казан университеты, 2011. 2 нче китап: XX йөзнең икенче яртысында татар әдәбияты [Книга 2: Татарская литература второй половины XX в.]. 196 б. (На татар. яз.)

\footnotetext{
${ }^{1}$ Как свидетельствуют работы А. В. Смирнова, для арабо-мусульманской поэтологии принципиальным и неустранимым моментом является адресация к смыслу, в связи с чем здесь многое понимается иначе, нежели в западной традиции. Нахождение смысла здесь требует не абстрагирующего очищения от специфицирующих признаков, а перехода от отдельных явлений к той области, которая лежит вне их и в которой они совпадают. Родо-видовые механизмы осмысления содержания понятий и изложения материала блокируются художественным сознанием мусульманского Востока с его столь же фундаментальной и универсально признаваемой теорией «указания на смысл» (Смирнов, 2001).
} 
Имихелова, С. С., Болдонова, И. С. (2017) Отражение кризиса самоидентификации личности в литературе позднесоветского времени // Вестник Бурятского государственного университета. Вып. 2. С. 148-155.

Калзан, А. К. (1991) Өзүлдениң демдектери [Приметы роста]. Кызыл : Тувин. кн. изд-во. 304 с. (На тув. яз.)

Корман, Б. О. (2006) Избранные труды. Теория литературы. Ижевск : Ин-т компьютерных исследований. 552 с.

Кошелева, А. Л. (2016) Парадигма образного воплощения и имманентного синтеза категорий «Пространство», «Время» и «Человек» в лирико-философской поэме народного писателя Республики Тыва Э. Мижита «Пируэты мысли» // Филология и культурология: современные проблемы и перспективы развития: сборник материалов 20-й международной научно-практической конференции, (г. Махачкала, 15 мая 2016 г.). Махачкала : Издательство «Апробация». 83 с. С. 20-24.

Лейдерман, Н. Л., Липовецкий, М. Н. (2001) Современная русская литература: в 3 кн. М. : Эдиториал УРСС. Кн. 2: Семидесятые годы. 288 с.

Мижит, Л. С. (2013) Тувинское трехстишие. Триада в тувинской традиционной культуре. Новосибирск : Изд-во CO РAH. 138 c.

Мижит, Л. С. (2015) Тыва шүлүк чогаалының делегейинде [Мир тувинской поэзии]. Кызыл : Тываполиграф. 170 с. (На тув. яз.)

Миңнегулов, Х. Ю. (1995) Шигъри сүзгә тугрылык [Верность поэтическому слову] // Мирас. № 3. 44-46 б. (На татар. яз.)

Псху, А. А.-К. (2007) Национальный мир и художественные образы лирики Микаэля Чикатуева : автореф. дис.... к. ф. н. Нальчик. 23 с.

Родионов, В. Г., Родионова, Э. В. (2019) Геннадий Айги в контексте чувашской литературной жизни второй половины XX века. Чебоксары : ЧГТГН. 84 с.

Самдан, 3. Б. (2005) Тыва чогаалдың кокпалары-биле [По тропам тувинской словесности]. Кызыл : Респ. типогр. 160 с. (На тув. яз.)

Смирнов, А. В. (2001) Номинативность и содержательность: почему некритическое исследование «универсалий культуры» грозит заблуждением // Универсалии восточных культур / отв. ред. М. С. Степанянц. М. : Изд. фирма «Восточная литература». 431 с. С. 290-317.

Соян, А. М. (2018) Образы-символы в поэмах Э. Мижита // Мир науки, культуры, образования. № 6 (73). С. $563-564$.

Султанов, К. К. (2008) Этнокультурная идентичность как проблема литературоведческого анализа // Международные Ломидзевские чтения. Изучение литератур и фольклора народов России и СНГ: Теория. История. Проблемы современного развития. М. : ИМЛИ РАН. 472 с. С. 338-347.

Тыва уран чогаал: сөөлгү үениң шинчилелдери [Тувинская литература: современные исследования] (2009) / составитель Л. С. Мижит. Кызыл : Тываполиграф. 208 с. (На тув. яз.)

Шибанов, В. Л. (2012) Удмуртская поэзия конца XX - начала XXI вв. // Национальные литературы республик Поволжья (1980-2010 гг.) / науч. ред. В. Р. Аминева. Барнаул : ИГ «Си-пресс». 234 с. С. 161-176.

Yuzmukhametova, L. N., Amineva, V. R., Shimonik, D. (2018) Comparative poetics as a method of studying inter literary dialogues // Opcion. Vol. 34, Is. Special Issue 17. P. 1006-1016.

Дата поступления: 01.02.2021 2.

\section{REFERENCES}

Amineva, V. R. (2016) Ne-(post) klassicheskaya kartina mira v natsional'nom istoriko-literaturnom protsesse (na materiale liriki R. Akhmetzyanova) [Non-(post) classical picture of the world in the national historical and literary process: the poetry of R. Akhmetzyanov)]. Studia Litterarum, vol. 1 (3-4), pp. 278-297. (In Russ.)

Bakhtin, M. M. (1986a) Estetika slovesnogo tvorchestva [Aesthetics of verbal art]. $2^{\text {nd }}$ ed. Moscow, Iskusstvo. 445 p. (In Russ.)

Bakhtin, M. M. (1986b) Problemy teksta v lingvistike, filologii i drugikh gumanitarnykh naukakh [The problem of the text in linguistics, philology and other humanities]. In: Bakhtin M. M. Estetika slovesnogo tvorchestva [Aesthetics of verbal creativity]. $2^{\text {nd }}$ ed. Moscow, Iskusstvo. 445 p. Pp. 297-325. (In Russ.)

Bakhtin, M. M. (2003) Sobraniye sochineniy [Collected works]: in 7 vols. Moscow, Russkiye slovari; Yazyki slavyanskikh kul'tur. Vol. 1.958 p. (In Russ.)

Broytman, S. N. (1997) Russkaya lirika XX - nachala XXI vekov v istoricheskoy poetiki. Sub'yektno-obraznaya struktura [Russian lyrics of the $19^{\text {th }}$ - early $20^{\text {th }}$ centuries in the light of historical poetics: a subject-image structure]. Moscow, Rossiysk. gos. gumanit. un-t. 307 p. (In Russ.) 
Valikova, O. A., Shagimgireyeva, B. Ye. and Kuliyeva Sh. A. Kosmos v logose: translingval'naya poeziya Eduarda Mizhita i Bakhyta Kairbekova [Cosmos in Logos: Translingual Poetry by Eduard Mizhit and Bakhyt Kairbekov]. New Research of Tuva, no. 4, pp. 230-249. (In Russ.) DOI: www.doi.org/10.25178/nit.2020.4.16

Gadzhiyeva, Z. Z. (2015) Zhanr ispovedi v tvorchestve avarskikh poetov v epokhu «dushevnogo tomleniya» [The genre of confession in the poetry of Avar poets in the epoch of "Mental languor"]. Vestnik instituta yazyka, literatury $i$ iskusstva im. G. Tsadasy, no. 8, pp. 107-117. (In Russ.)

Ganieva, R. K. (2009) Zamannyng shig'ri pəigambəre [The poetic prophet of his time]. In: Gatashnamə. Rədif GataullinGatash iжsaty turynda səkhifalər. Məkalalər, esselar, shigyr'lər [A Book of Gatasi: The works of R. Gataullin-Gatash]. Kazan', Dom pechati. 439 p. Pp. 370-377. (In Tatar)

Grigor'yeva, T. P. (1982) Daosskaya i buddiyskaya modeli mira (predvaritel'nyye zametki) [Taoist and Buddhist Models of the World (preliminary notes)]. In: Dao i daosizm v Kitaye [Tao and Taoism in China]. Ed. by L. S. Vasilyev and E. B. Porshneva. Moscow, Nauka. 289 p. Pp. 159-178. (In Russ.)

Dampilova, L. S. (2014) Motivnichestva dvoynichestva v poezii Eduarda Mizhita [The motif of duality in the poetry of Eduard Mizhit]. Sibirskiy filologicheskiy zhurnal, no. 3, pp. 158-163. (In Russ.)

Dongak, U. A. (2014) Ivolgi napev zhivoy: V novom oblike drevnego slova [The golden oriole's chant: The new guise of an ancient word]. Abakan, Zhurnalist. 288 p. (In Russ. and Tuv.)

Dongak, U. A. (2020) Novatorstvo pisatelya-bilingva Eduarda Mizhita (tuvinskaya poeziya) [New poetic methods in the literary imagination of the bilingual writer Eduard Mizhit (Tuvan poetry)]. Polylinguality and transcultural practices, vol. 17, no. 4, pp. 462-474 (In Russ.) DOI: www.doi.org/10.22363/2618-897X-2020-17-4-462-474

Durišin, D. (1979) Teoriya sravnitel'nogo izucheniya literatury [Theory of literary comparatistics] / Transl. from Slov. Moscow, Progress. 320 p. (In Russ.)

Zagidullina, D. F. (2015) 1960-1980 ellar tatar adəbiiaty: iangarysh maidannary həm avangard ezlanülar [The Tatar literature of the 1960-1980s: avant-garde experimentation]. Kazan', Tatar book publ. 383 p. (In Tatar.)

Zahidullina, D. F. and Yusypova, N. M. (2011) XX gasyr tatar adabiiaty tarikhy: dareslek [Tatar literature of the 20 $0^{\text {th }}$ century]: in 2 books. Kazan, Kazan universitety. Book 2. Tatar literature of the second half of the XX century. 196 p. (In Tatar.)

Imikhelova, S. S. and Boldonova, I. S. (2017) Otrazheniye krizisa samoidentifikatsii lichnosti v literature pozdnesovetskogo vremeni [The reflection of the self-identification crisis in the literature of the late Soviet period]. Vestnik Buryatskogo gosudarstvennogo universiteta, vol. 2, pp. 148-155. (In Russ.)

Kalzan, A. K. (1991) Özüldening demdekteri [Signs of growth]. Kyzyl, Tuvan book publisher. 304 p. (In Tuv.)

Korman, B. O. (2006) Izbrannyye trudy. Teoriya literatury [Selected works. Theory of literature]. Izhevsk, Institute of Computer Research. 552 p. (In Russ.)

Kosheleva, A. L. (2016) Paradigma obraznogo voploshcheniya i immanentnogo pisatelya kategoriy «Prostranstvo», «Vremya» $\mathrm{i}$ «Chelovek» v liriko-filosofskoy poeme narodnogo gosudarstva Respubliki Tyva E. Mizhita «Piruety mysli» [The paradigm of the figurative embodiment and immanent synthesis of the categories of "Space”, “Time” and "Man" in the philosophical poem "Pirouettes of Thought” by the People's Writer of the Republic of Tuva E. Mizhit]. In: Filologiya i kul'turologiya: sovremennyye problemy i perspektivy razvitiya [Philology and Cultural Studies: modern problems and Prospects of Development]: collection of materials of the 20th International Scientific and Practical Conference, (Makhachkala, May 15, 2016). Makhachkala, Aprobatsiya Publ. 83 p. Pp. 20-24. (In Russ.)

Leiderman, N. L. and Lipovetskii M. N. (2001) Sovremennaia russkaia literature [Modern Russian literature]: in 3 books. Moscow, Editorial URSS. Book 2: Semidesiatye gody [The seventies]. 288 p. (In Russ.)

Mizhit, L. S. (2013) Tuvinskoe trekhstishie. Triada $v$ tuvinskoi traditsionnoi kul'ture [Tuva tercet: the Triad in Tuvan traditional culture]. Novosibirsk, Izd-vo SO RAN. 138 p. (In Russ.).

Mizhit, L. S. (2015) Tyva shülük chogaalynyng delegeiinde [The world of Tuvan poetry]. Kyzyl, Tyvapoligraf. 170 p. (In Tuv.)

Mingnegulov, Kh. Yu. (1995) Shig'ri süzgə tugrylyk [Faithful to the poetic word]. Miras, no. 3, pp. 44-46. (In Tatar.)

Pskhu, A. A.-K. (2007) Natsional'nyy mir i khudozhestvennyye obrazy liriki Mikaelya Chikatuyeva [The ethnic world and imagery in the lyrics by Mikael Chikatuev] : Abstract of Diss.... Candidate of Philology. Nal'chik. 23 p. (In Russ.)

Rodionov, V. G. and Rodionova, E. V. (2019) Gennadiy Aygi v kontekste chuvashskoy literaturnoy zhizni vtoroy poloviny XX veka [Gennady Aigi in the context of the Chuvash literary life of the second half of the $20^{\text {th }}$ century]. Cheboksary, CHGTGN. 84 p. (In Russ.)

Samdan, Z. B. (2005) Tyva chogaaldyng kokpalary-bile [On the paths of Tuvan literature]. Kyzyl, Resp. tipogr. 160 p. (In Tuv.) 
Smirnov, A. V. (2001) Nominativnost' i soderzhatel'nost': pochemu nekriticheskoye issledovaniye «universaliy kul'tury» grozit zabluzhdeniyem [Nominativity and substance: why noncritical research of "cultural universalia" may delude us]. In: Universalii vostochnykh kul'tur [Universalia of Eastern Cultures]. Ed. by M. S. Stepanyaynst. Moscow, Vostochnaya literatura. 431p. Pp. 290-317. (In Russ.)

Soyan, A. M. (2018) Obrazy-simvoly v poemakh E. Mizhita [Symbolic imagery in the poems by E. Mizhit]. Mir nauki, kul'tury, obrazovaniya, no. 6 (73), pp. 563-564. (In Russ.)

Sultanov, K. K. (2008) Etnokul'turnaya identichnost' kak problema literaturovedcheskogo analiza [Ethnocultural identity as a problem of literary analysis]. In: Mezhdunarodnyye Lomidzevskiye chteniya. Izucheniye literatur i fol'klora narodov Rossii i SNG: Teoriya. Istoriya. Problemy sovremennogo razvitiya [International Lomidze Readings. Studying the literature and folklore of the peoples of Russia and the CIS: Theory. History. Problems of modern development]. Moscow, IMLI RAN. 472 p. Pp. 338-347. (In Russ.)

Tyva uran chogaal: söölgü üening shinchilelderi [Tuvan literature: modern research] (2009) / comp. by L. S. Mizhit. Kyzyl, Tyvapoligraf. 208 p. (In Tuv.)

Shibanov, V. L. (2012) Udmurtskaya poeziya kontsa XX - nachala XXI vv. [Udmurt poetry of the late $20^{\text {th }}$ and early $21^{\text {st }}$ centuries.]. In: Natsional'nyye literatury respublik Povolzh'ya (1980-2010 gg.) [National literatures of the republics of the Volga region, 1980-2010] / ed. by V. R. Amineva. Barnaul, IG «Si-press». 234 p. Pp. 161-176. (In Russ.)

Yuzmukhametova, L. N., Amineva, V. R. and Shimonik, D. (2018) Comparative poetics as a method of studying inter literary dialogues. Opcion, vol. 34, Special Issue 17, pp. 1006-1016.

Submission date: 01.02.2021. 